PLAYING AMERICA'S GAME 


\section{AMERICAN CROSSROADS}

Edited by Earl Lewis, George Lipsitz, Peggy Pascoe, George Sánchez, and Dana Takagi 


\section{Playing America's Game}

Baseball, Latinos, and the Color Line

Adrian Burgos Jr.

甲ㅜ

UNIVERSITY OF CALIFORNIA PRESS Berkeley Los Angeles London 
University of California Press, one of the most distinguished university presses in the United States, enriches lives around the world by advancing scholarship in the humanities, social sciences, and natural sciences. Its activities are supported by the UC Press Foundation and by philanthropic contributions from individuals and institutions. For more information, visit www.ucpress.edu.

University of California Press

Berkeley and Los Angeles, California

University of California Press, Ltd.

London, England

(C) 2007 by The Regents of the University of California

Library of Congress Cataloging-in-Publication Data

Burgos, Adrian, I969-

Playing America's game : baseball, Latinos, and the color line / Adrian Burgos Jr.

p. $\quad \mathrm{cm} .-$ (American crossroads ; 23)

Includes bibliographical references and index. ISBN 978-0-520-23646-2 (cloth : alk. paper) ISBN 978-0-520-25I43-4 (pbk. : alk. paper)

I. Hispanic American baseball players-History. 2. Baseball-United States-History. 3. Racism in sports-United States-History. 4. United States-Race relations. I. Title.

GV863.AIB $844 \quad 2007$

$796.357-\mathrm{dc} 22$

2007002883

Manufactured in the United States of America

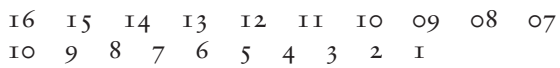

This book is printed on New Leaf EcoBook 60, containing $60 \%$ post-consumer waste, processed chlorine free; $30 \%$ de-inked recycled fiber, elemental chlorine free; and Io\% FSC-certified virgin fiber, totally chlorine free. EcoBook 60 is acid-free and meets the minimum requirements of ANSI/ASTM D 5634-OI (Permanence of Paper). 
In memory of those who entered the U.S. playing field and were not recognized, and for Dolly, Miranda, and my parents, Aida Burgos and Adrian Burgos Sr. 
